\title{
Identification of new Brome mosaic virus (BMV) isolates systemically infecting Vigna unguiculata $\mathrm{L}$
}

\author{
Katarzyna Trzmiel • Aleksandra Zarzyńska-Nowak • \\ Marzena Lewandowska • Wiktoria Szydło
}

Accepted: 29 November 2015 / Published online: 8 December 2015

(C) The Author(s) 2015. This article is published with open access at Springerlink.com

\begin{abstract}
Here we describe two Brome mosaic virus (BMV) isolates from the Wielkopolska region of Poland. The BMV-Sr and BMV-Sz isolates were collected from maize [Zea mays L. ssp. Indentata] and triticale $[\times$ Triticosecale Wittm. ex A. Camus] plants respectively. Newly emerged BMV isolates, similarly to the BMV-M2 strain derived from an Arkansas isolate, have a wide host range that includes species in the Poaceae and Fabaceae families. Furthermore, immunological reactions of icosahedral virions from non-inoculated cowpea [Vigna unguiculata L.] leaves with a specific immunoglobulin confirmed that each of these isolates can systemically infect cowpea. We characterized the BMV-Sr and BMV-Sz genomic sequences encoding the replication protein (1a), polymerase (2a), complete movement protein (3a) and coat protein (CP) genes. The 1a, 2a, 3a and CP gene sequences showed 98.9, 97.6, 98.4 and $97.7 \%$ nucleotide sequence identity between the Polish isolates respectively. Phylogenetic analysis based on these four genes confirmed the species identity of the isolates. A phylogenetic tree based on
\end{abstract}

Electronic supplementary material The online version of this article (doi:10.1007/s10658-015-0830-5) contains supplementary material, which is available to authorized users.

K. Trzmiel $(\bowtie) \cdot$ A. Zarzyńska-Nowak $\cdot$ M. Lewandowska Institute of Plant Protection-National Research Institute, Władysława Węgorka 20, 60-318 Poznań, Poland e-mail: k.trzmiel@iorpib.poznan.pl

W. Szydło

Department of Animal Taxonomy and Ecology, Adam Mickiewicz University, Umultowska 89, 61-614 Poznań, Poland
RNA3 (3a and CP genes) showed independent clustering of the Polish isolates. Amino acid sequence analysis of the $3 \mathrm{a}$ protein revealed that both Polish isolates are characterized by a single amino acid mutation at the 81st position, when compared with the Russian isolate. It had been previously reported that four amino acid mutations in this region determined BMV systemic infection in cowpea. Our results indicate that a single non-synonymous substitution in the cell-to-cell movement protein may be crucial for the nature of cowpea infection.

\section{Keywords BMV·Zea mays $\cdot$ Triticosecale $\cdot$ Vigna} unguiculata $\cdot$ Mutation $\cdot$ Infection

\section{Introduction}

Brome mosaic virus (BMV), the type member of the Bromovirus genus, has a tripartite genome. RNAs 1 and 2 encode the 1a and 2a proteins respectively, which are necessary for virus replication. The 3 a protein encoded by RNA 3 is required for cell-to-cell movement, whereas the subgenomic RNA 4, expressed from the 3'-end of RNA3, encodes the coat protein. The three genomic RNAs are encapsulated in three separate icosahedral virions but subgenomic RNA 4 is co-encapsulated with RNA3 (Ni et al. 2014). BMV is the conventional model for studies on viral gene expression, RNA replication, RNA recombination, encapsidation and virus-host interaction (Scholthof et al. 2011). However, there is a dearth of available information about the genetic variability 
and diversity of this virus; the National Center for Biotechnology Information (NCBI) GenBank database contains only five complete BMVs genome sequences originating from natural hosts.

BMV has a wide natural host range within the Poaceae family, including cereals: Avena sativa L., Hordeum vulgare L., Secale cereale L., Triticum estivum L., $\times$ Triticosecale Wittm. ex A. Camus, Zea mays L. and can mechanically transmitted to dicotyledonous plants classified into a few genera of approximately six families (Lane 1974). BMV viral infection induces a mosaic or streaked pattern of chlorosis on infected leaves (Mise and Pocsai 2004) as well as reduced plant height and weight (Poscai 1987). Although BMV can be transmitted mechanically, it is principally spread by invertebrate vectors: mainly beetles [several species of the Oulema and Phylotrella genera (Arthropoda: Insecta: Coleoptera: Chrysomelidae) (Szabolcs and Gáborjányi 1991)], dagger nematodes Xiphinema spp. (Nematoda: Adenophorea: Dorylaimida: Longidoridae) (Fritzsche 1975) and aphids (Insecta: Hemiptera: Aphididae) (Rybicki and von Wechmar 1982). Transmission is also possible with fungal infection of Puccinia graminis Pers. (von Wechmar 1980). Seed transmission of BMV has not been reported (Mise and Pocsai 2004). BMV infections have been reported in the USA, South Africa and Europe (Lane 1977). In Poland, BMV was first reported on T. aestivum plants (Jeżewska and Wieczorek 1999). Here we report two newly recognized natural isolates of BMV from Poland.

To date, the presence of BMV in Poland has been confirmed only in the Wielkopolska region, where it appeared sporadically. BMV-Sz was isolated from triticale plants naturally co-infected with Wheat streak mosaic virus (WSMV), collected from Szelejewo in 2013 (Trzmiel et al. 2015). The single infection of $\mathrm{BMV}-\mathrm{Sz}$ was also detected in cocksfoot plants (Dactylis glomerata L.) in Gorzyń in 2014. BMV-Sr was isolated from stunted maize plants with leaf mosaic symptoms found near Środa Wielkopolska in 2013. A new BMV isolate was recently identified in Hordeum murinum L. collected in Poznań. These isolates were maintained on barley cv. Bażant by mechanical inoculation within a greenhouse. Biological tests confirmed the infectivity of BMV-Sr and BMV-Sz isolates to Poaceae family members. Both isolates were efficiently transmitted to T. aestivum, $H$. vulgare, A. sativa, S. cereale, $\times$ Triticosecale and Bromus hordaceus L. and induced systemic leaf mosaic symptoms. Mechanical inoculation of fodder maize (Z. mays ssp. Indentata) resulted in leaf mosaic symptoms, whereas in sweet maize (Z. mays ssp. Saccharata) lesions were followed by systemic necrosis and death, as is typically for this virus (Mise and Pocsai 2004). Furthermore, both BMV isolates caused local and subsequently systemic reaction of Chenopodium quinoa Willd and necrotic local lesions on Datura festuosa L. and D. stramonium L. leaves, with local and systemic symptoms appearing at 5-6 and 1516 days post-inoculation respectively. Moreover, BMV-Sr and BMV-Sz, similarly to BMV-M2 originally derived from BMV-1 from Arkansas, induced systemic reaction of cowpea (Vigna unguiculata L.) (De Jong and Ahlquist 1995). Similar to the American isolate, the Polish isolates caused necrotic lesions on inoculated leaves. However, BMV-M2 induced severe vein yellowing and/or chlorotic mosaic on non-inoculated cowpea leaves (De Jong et al. 1995). while BMV-Sr and BMV-Sz developed generally symptomless infection and only few plants (2-3 from 10 inoculated plants) showed chlorotic flecking of younger leaves. Following the inoculation with BMV-Sr and -Sz, virus presence in non-inoculated cowpea leaves was verified by an ELISA assay (Clark and Adams 1977) using a commercial kit (Loewe Biochemica GmbH, Sauerlach, Germany). Of 10 examined plants, systemic BMV-Sr and BMV-Sz infections were identified in 4 and 5 plants respectively. The optical density (OD) values for infected plants ranged from 0.080 to 0.800 , compared to 0.012 for healthy plants. Crude sap from non-inoculated leaves of infected cowpea plants was negatively stained with $2 \%$ Phosphotungstic acid ( $\mathrm{pH}$ 7.2) and was also used in immunoelectron microscopy (IEM) with a 100-fold dilution of the commercial available anti-BMV $\gamma$-globulin antibody (Loewe Biochemica $\mathrm{GmbH}$ ) and examined under a Hitachi HT7700 transmission electron microscope at an acceleration voltage of $80 \mathrm{kV}$. Electron microscopy observations revealed the presence of single spherical particles of about $25-30 \mathrm{~nm}$ in diameter and characteristic of BMV (data not shown).

Newly identified BMV isolates were propagated and purified for molecular characterization. Systemically infected barley leaves were harvested at about 3-4 weeks post-inoculation and homogenized in three volumes of $0.25 \mathrm{M}$ sodium/potassium phosphate buffer ( $\mathrm{pH} 7.0$ ) containing $0.5 \%$ mercaptoethanol and $0.01 \mathrm{M}$ EDTA. The extract was filtered through cheesecloth and $1 \%$ Triton X-100 was added. The obtained mixture was incubated at $4{ }^{\circ} \mathrm{C}$ for $1 \mathrm{~h}$ and subsequently centrifuged 
at $10,000 \times \mathrm{g}$ for $10 \mathrm{~min}$ at $4{ }^{\circ} \mathrm{C}$. The supernatant was subsequently centrifuged through a layer of $20 \%$ sucrose at $80,000 \times \mathrm{g}$ for $2 \mathrm{~h}$. The obtained pellet was re-suspended in $0.25 \mathrm{M}$ sodium/potassium phosphate buffer $(\mathrm{pH} 7.0)$ and again centrifuged through a layer of $10 \%$ sucrose under the same conditions. The pellet was dissolved in small amount $(\sim 1.5 \mathrm{ml})$ of $0.25 \mathrm{M}$ sodium/potassium phosphate buffer. Viral RNA from partially purified virus was isolated according to Sambook et al. (1989) or alternatively with the NucleoSpin ${ }^{\circledR}$ RNA Plant kit (Macherey-Nagel, Düren, Germany) according to the manufacturer's instructions. RNA was diluted in $40 \mu \mathrm{l}$ of autoclaved water and stored at $-20{ }^{\circ} \mathrm{C}$. The RNA profile was analyzed by $1 \%$ agarose gel electrophoresis under denaturing conditions. Four bands with estimated sizes of about $4,3,2$ and $0.5 \mathrm{~Kb}$ were seen after electrophoresis (data not shown). This separation corresponds to the genome size of BMV, where RNA1, RNA2, RNA3, and sgRNA4 are 3234, 2865, 2114 and 876 nucleotides long respectively (Mise and Pocsai 2004). Isolated RNA was subsequently used in RT-PCR with a set of originally designed primers targeting the 1a protein (replication protein), 2a polymerase (RNA - dependent RNA polymerase), 3a protein (movement protein) and coat protein (CP) coding regions using the Primer3 software (http://frodo. wi.mit.edu) (Rosen and Skaletsky 2000) based on the conserved regions of full-length BMV sequences retrieved from NCBI GenBank (Table 1). First-strand cDNAs were synthesized using SuperScript ${ }^{\circledR}$ Reverse Transcriptase (Thermo Fisher Scientific, Waltham, MA, USA) with random hexamer primers following the manufacturer's instructions. The PCR was carried out using $1 \mu \mathrm{l}$ of RT mixture with $1 \mu \mathrm{l} 10 \times$ AccuPrimeTM PCR Buffer II, $0.2 \mu \mathrm{l}$ Primer Mix (10 $\mu \mathrm{mol} / \mu \mathrm{l}$ each), $0.25 \mu \mathrm{l}$ AccuPrimeTM Taq DNA Polymerase (Thermo Fisher Scientific) and sterile Milli-Q water for a final volume of $10 \mu \mathrm{l}$. Amplification was performed as follows: $94{ }^{\circ} \mathrm{C}$ for $2 \mathrm{~min}, 35$ cycles of $94{ }^{\circ} \mathrm{C}$ for $30 \mathrm{~s}, 55^{\circ} \mathrm{C}$ for $30 \mathrm{~s}$, $68{ }^{\circ} \mathrm{C}$ for $1 \mathrm{~min}$ and a final cycle of $68^{\circ} \mathrm{C}$ for $5 \mathrm{~min}$. PCR products were separated by $1 \%$ agarose gel electrophoresis and stained with Midori Green DNA Stain (NIPPON genetics Europe GmbH, Düren, Germany) for UV light visualization. The PCR products of expected size (Table 1) were excised from the agarose gel, purified using the Wizard ${ }^{\circledR}$ SV Gel and PCR Clean-Up System (Promega Corp., Madison, WI, USA), ligated into the pGEM-T Easy Vector (Promega) and then transformed into Escherichia coli TOP10 competent chemical cells (Thermo Fisher Scientific). Plasmid DNA was isolated using NucleoSpin ${ }^{\circledR}$ Plasmid (NoLid) (Macherey-Nagel) according to the manufacturer's instructions. Subsequently, three clones of each fragment were commercially sequenced by Genomed S.A. (Warsaw, Poland) or by Molecular Techniques Laboratory, Faculty of Biology, Adam Mickiewicz University (Poznań, Poland) in both directions with M13-F and M13-R primers. The nucleotide sequences were analyzed using Standard Nucleotide BLAST (BLASTN, http://blast.ncbi.nlm. nih.gov/Blast.cgi), compiled, edited in the BioEdit software (Hall 1999) and deposited in the NCBI GenBank Database with the following accession numbers for genome fragments of BMV-Sr (KP137564, KP137565, KP137566, KP096132) and BMV-Sz (KP161269, KP137567, KP137568, KP096133). Partial coding sequences of the $1 \mathrm{a}$ and $2 \mathrm{a}$ and complete nucleotide sequences of $3 \mathrm{a}$ and $\mathrm{CP}$ genes for BMV-Sr and $\mathrm{BMV}-\mathrm{Sz}$ isolates were determined and compared with corresponding fragments of other known BMV isolates (Table 2). The alignments of nucleotide sequence of BMV-Sr revealed nucleotide sequence identity of between 98.2 and $99.0 \%$ for 1a protein; 98.3 and $98.9 \%$ for 2 a protein; 98.3 and $99.2 \%$ for 3 a protein; and 96.4 and $98.5 \%$ for CP. The same analysis for BMV-Sz showed identity of between 98.4 and $98.9 \%$ for 1a protein; 97.2 and $97.9 \%$ for 2a protein; 97.9 and $98.4 \%$ for 3 a protein and 95.6 and $97.5 \%$ for CP. Results confirmed the highest amino acid homology in the region encoding polymerase $2 \mathrm{a}(99.2$ to $100 \%)$ and the highest divergence in the region encoding CP (97.3 to $99.4 \%)$, as was previously shown by Gadiou and Kundu (2010). A comparison of the obtained BMV-Sr and BMV-Sz RNA1, RNA2, RNA3 and CP sequences revealed nucleotide similarities of $98.9 \%$ (eight synonymous substitutions), 97 . $6 \%$ (18 synonymous substitutions), $97.7 \%$ (15 synonymous substitutions) and $97.1 \%$ (16 synonymous substitutions) respectively. The isolates differed in the length of their intercistronic poly(A)tracts (16 bases in length for BMV-Sr and 20 bases for BMV-Sz) but were within the previously reported length range for BMV (De Jong et al. 1995).

Phylogenetic analyses of the nucleotide sequences were conducted for two Polish (-Sr and $-\mathrm{Sz}$ ) and five previously characterized $(-\mathrm{Cz},-$ Fescue, $-\mathrm{KU} 1$, $-\mathrm{M} 2$, -Russian) BMV isolates, as well as for four species of Bromovirus genus (Cowpea chlorotic mottle 
Table 1 Primers used in the study

\begin{tabular}{llcl}
\hline Primer & Primer sequence 5' - 3' & Position * & Amplicon size (bp) \\
\hline BMV1-F & GAGTCGGTGCATTGCATCGAT & $858-878$ & 830 \\
BMV1-R & ACGGACTCAGGGCTCGAACTC & $1681-1661$ & 798 \\
BMV2-F & CTATAGCAAAGCGCTTTCGT & $1086-1105$ & 780 \\
BMV2-R & CAAACGTAGGGCACACTAGGG & $1884-1864$ & 165 \\
BMV3-F & CCCAGGAAGATTTGTTAGTTG & $110-129$ & \\
BMV3-R & CAACTAACAAATCTTCCTGGG & $890-870$ & 639 \\
BMV3-1-F & GTAAAATACCAACTAATTCTC & $1-19$ & \\
BMV3-1-R & GTACCTCCCGCTTGCTTGCC & $165-146$ & $722-740$ \\
BMV3-2-F & GGTCCCGCTACAATTATGG & $1361-1341$ & 626 \\
BMV3-2-R & GCCTTGGCCAGCAGCGAGTGG & $1213-1232$ & $1839-1819$ \\
BMVcp-F & GATCTATGTCCTAATTCAGCG & \\
BMVcp-R & CCAGTCAGGGGCTCTCCGAGC & \\
\hline
\end{tabular}

*The primers position according BMV-Cz RNA-1, RNA-2, RNA-3 (Ac. NoGU584131, GU584130 and GU584129, respectively)

virus [CCMV], Cassia yellow blotch virus [CYBV], Spring beauty latent virus [SBLV] and Broad bean mottle virus [BBMV]) for which the full length of the genome sequence was determined (Fig. 1a), with Olive latent virus (member of Bromoviridae family, Oleavirus genus) as an outgroup. Multiple alignment and concatenation of datasets were performed in MEGA6 (Tamura et al. 2013). Best fit nucleotide substitution models for each sequence dataset were chosen with jModeltest v.2.1.3 (Darriba et al. 2012) under Bayesian information criterion (BIC) (Schwarz 1978; Ripplinger and Sullivan 2008). GTR $+\mathrm{G}$ for the $1 \mathrm{a}$ dataset, $\mathrm{HKY}+\mathrm{G}$ for the $2 \mathrm{a}$ dataset, $\mathrm{K} 2 \mathrm{P}+\mathrm{I}+\mathrm{G}$ for the $3 \mathrm{a}$ dataset and $\mathrm{K} 2 \mathrm{P}+\mathrm{G}$ for the $\mathrm{CP}$ dataset. The Bayesian inference (BI) of phylogeny of the concatenated datasets was performed with MrBayes 3.2 (Ronquist et al. 2012). The output tree topology with a well-supported clade of BMV confirmed the species identity of the new isolates (Fig. 1a). The neighbor joining (NJ) analysis of the dataset of complete $3 \mathrm{a}$ and $\mathrm{CP}$ coding sequences of BMV isolates was done in MEGA6 using the K2P model (with SBLV as an outgroup). The differences in genetic variation in the $3 \mathrm{a}$ and $\mathrm{CP}$ coding regions of $\mathrm{BMV}$ resulted in tree incongruence, however, both resulting topologies show $\mathrm{BMV}-\mathrm{Sz}$ and $\mathrm{BMV}-\mathrm{Sr}$ isolates clustering with each other (Fig. $1 \mathrm{~b}$ and c). The $3 \mathrm{a}$ tree (Fig. 1b) consisted of two main clades: 1) the Polish isolates BMV-Sz and -Sr clustered with the Czech isolate BMV-Cz; and 2) BMV-M2 (Type isolate) with KU1 and -Fescue. The Russian isolate sequence did not cluster with any other isolate. The CP tree (Fig. 1c) also comprised two main clades: a clade of BMV-Sz and -Sr and a clade of BMV-M2, -KU1, -Fescue and -Rus, with BMV-Cz remaining un-clustered.

Table 2 Percentage of nucleotide/amino acid sequences identity of different genome regions between BMV-Sr, BMV-Sz and other known BMV isolates

\begin{tabular}{|c|c|c|c|c|c|c|c|c|}
\hline \multirow[t]{2}{*}{ BMV isolate* } & \multicolumn{2}{|c|}{ Replication protein $1 \mathrm{a}$} & \multicolumn{2}{|c|}{ Polymerase $2 \mathrm{a}$} & \multicolumn{2}{|c|}{ Movement protein $3 \mathrm{a}$} & \multicolumn{2}{|c|}{ Coat protein } \\
\hline & $\mathrm{BMV}-\mathrm{Sr}$ & $\mathrm{BMV}-\mathrm{Sz}$ & $\mathrm{BMV}-\mathrm{Sr}$ & BMV-Sz & $\mathrm{BMV}-\mathrm{Sr}$ & $\mathrm{BMV}-\mathrm{Sz}$ & $\mathrm{BMV}-\mathrm{Sr}$ & BMV-Sz \\
\hline $\mathrm{BMV}-\mathrm{Cz}$ & $98.2 / 99.6$ & $98.4 / 99.6$ & $98.6 / 100$ & $97.9 / 100$ & $98.3 / 98.3$ & 97. $9 / 98.3$ & $96.4 / 97.3$ & $95.6 / 97.3$ \\
\hline BMV-Fescue & 99.0/99.6 & 98.9/99.6 & $98.3 / 99.6$ & $97.2 / 99.6$ & $99.1 / 99.6$ & $98.4 / 99.6$ & $98.2 / 98.9$ & $97.3 / 98.9$ \\
\hline BMV-KU1 & $98.9 / 99.2$ & $98.7 / 99.2$ & 98.6/99.6 & 97.9/99.6 & $98.7 / 99.0$ & $98.1 / 99.0$ & $97.3 / 97.8$ & $96.4 / 97.8$ \\
\hline BMV-M2 & $99.0 / 99.6$ & 98.6/99.6 & $98.6 / 99.2$ & $97.7 / 99.2$ & $98.9 / 99.0$ & $98.2 / 99.0$ & 98.0/99.4 & $97.5 / 99.4$ \\
\hline BMV-Rus & $99.0 / 99.6$ & 98.9/99.6 & $98.9 / 100$ & $97.8 / 100$ & $99.1 / 99.6$ & $98.2 / 99.6$ & $98.5 / 99.4$ & $97.3 / 99.4$ \\
\hline
\end{tabular}

*GenBank accession numbers for BMV-Cz RNA1, RNA2, RNA3: GU584129 -GU584131; BMV-Fescue RNA1, RNA2, RNA3: DQ530423-DQ530425; BMV-KU1 RNA1, RNA2, RNA3: X58456-X58458; BMV-M2 RNA1, RNA2, RNA3: AB183261-AB183263; BMV-Russian (BMV-Rus) RNA1, RNA2, RNA3: X02380, X01678, J02042 


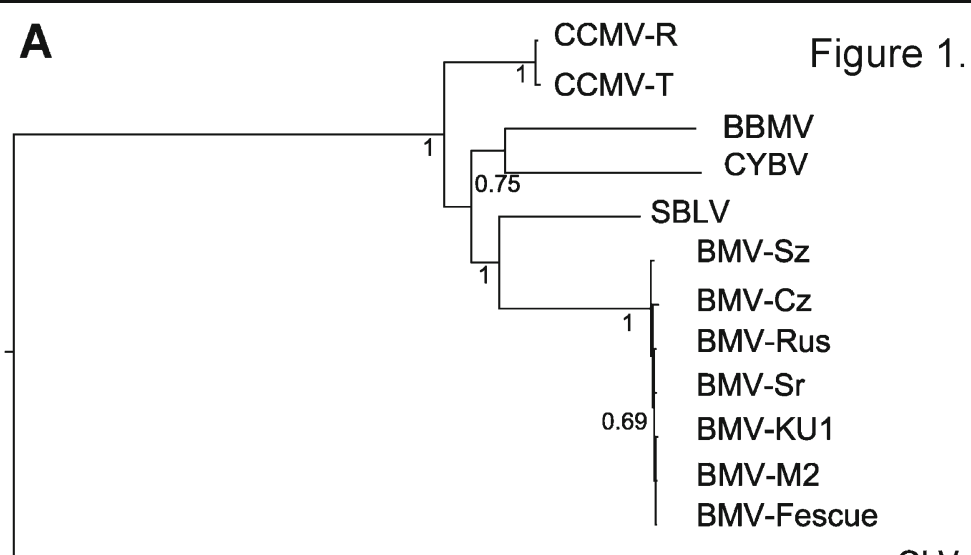

0.5

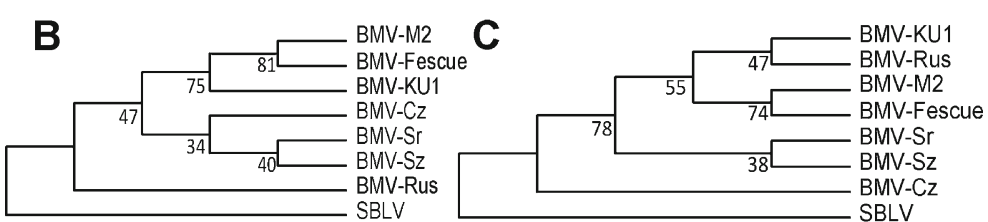

Fig. 1 The BI phylogenetic tree and NJ cladograms. a The BI tree of concatenated partial 1a, partial $2 \mathrm{a}$, complete $3 \mathrm{a}$ and complete $\mathrm{CP}$ coding sequence datasets of Bromoviridae. The values under the nodes represent posterior probabilities; values lower than 0.6 are not shown. b Cladogram of a NJ tree for 3 a complete sequence alignment. Values under the nodes represent percentage bootstrap support (1000 replicates). c Cladogram of a NJ tree for CP complete sequence alignment. Values under the nodes represent percentage bootstrap support (1000 replicates). Acronym

RNA3, particularly the cell-to-cell movement gene, plays an important role in determining the host specificity of BMV (De Jong and Ahlquist 1995). The studies of De Jong et al. (1995) reported four point mutations (at the 59th, 81st, 297th and 299th amino acid residues), which were essential to support systemic infection of cowpea plants. Therefore, the 3a protein amino acid sequences of BMV-Russian (typical host range) -M2, - Sr and -Sz (extended host range) were analyzed. The comparison of these sequences showed only one difference at the $81 \mathrm{st}$ amino acid residue. Our results indicated that this point mutation (from serine to proline) within the $3 \mathrm{a}$ protein resulted in less severe symptoms than BMVM2 but was sufficient to change the type of infection from local to systemic.

To our knowledge, this is the first report on BMV occurrence in maize plants in Europe. Both isolates were derived from economically important crops, while earlier reports principally addressed infections in wild grasses. Despite being well-studied under laboratory
BBMV stands for Broad bean mottle virus (M65138, M64713, M60291), CCMV-R and -T for Cowpea chlorotic mottle virus strain R and T (AF325736 - AF325738 and AF325739 AF325741), CYBV for Cassia yellow blotch virus (AB194806, $\mathrm{AB} 080599, \mathrm{AB} 080600)$, SBLV for Spring beauty latent virus (AB080598 - AB080600), OLV for Olive latent virus (NC_003673, NC 003674, NC 003671). BMV isolates are explained in Table 2. Trees were edited with FigTree v.1.4.2 (http://tree.bio.ed.ac.uk/software/figtree/)

conditions, there have been a limited number of field studies on the natural occurrence of BMV and its potential implications for cereal crops.

Acknowledgments The authors wish to thank Małgorzata Jeżewska (Institute of Plant Protection-National Research Institute, Poland) for critical remarks of the manuscript, Zofia Banaszak, Jacek Kaczmarek and Marcin Konieczny (Danko Plant Breeders LTD, Poland) for permission to collect plants and assistance in sampling, Henryk Pospieszny (Institute of Plant Protection-National Research Institute, Poland) for sharing the maize plant sample.

This study was partially funded by the National Science Centre, Poland, grant decision no. DEC-2011/01/N/NZ8/04540.

Open Access This article is distributed under the terms of the Creative Commons Attribution 4.0 International License (http:// creativecommons.org/licenses/by/4.0/), which permits unrestricted use, distribution, and reproduction in any medium, provided you give appropriate credit to the original author(s) and the source, provide a link to the Creative Commons license, and indicate if changes were made. 


\section{References}

Clark, M. F., \& Adams, A. N. (1977). Characteristics of the microplate method of enzyme-linked immunosorbent assay for the detection of plant viruses. Journal of General Virology, 34, 475-483.

Darriba, D., Taboada, G. L., Doallo, R., \& Posada, D. (2012). jModelTest 2: more models, new heuristics and parallel computing. Nature Methods, 9(8), 722. doi:10.1038/nmeth.2109.

De Jong, W., \& Ahlquist, P. (1995). Host-specific alterations in viral RNA accumulation and infection spread in a Brome mosaic virus isolate with an expanded host range. Journal of Virology, 69, 1485-1492.

De Jong, W., Chu, A., \& Ahlquist, P. (1995). Coding changes in the cell-to-cell movement gene can extend the host range of brome mosaic virus systemic infection. Virology, 214, 464- 474.

Fritzsche, R. (1975). Übertragung des Trespenmosaik - und Arabis-Mosaik-Virus durch Nematoden in Abhängigkeit von der Infektiosität der Wurzeln der Wirtspflanzen. Archiv für Phytopathologie und Pflanzenschutz Berlin, 11(3), 197-201.

Gadiou, S., \& Kundu, J. K. (2010). Complete genome sequence of a Brome Mosaic Virus isolate from the Czech Republic. Czech Journal of Genetics and Plant Breeding, 46(4), 178-182.

Hall, T. A. (1999). BioEdit: a user-friendly biological sequence alignment editor and analysis program for Windows 95/98/ NT. Nucleic Acids Symposium Series, 41, 95-98.

Jeżewska, M., \& Wieczorek, M. (1999). Some properties of an isolate of Brome mosaic virus. Phytopathologia Polonica, $17,23-30$.

Lane, L. C. (1974). The Bromoviruses. In M. A. Lauffer, F. B. Bang, K. Maramorosch, \& K. M. Smith (Eds.), Advances in Virus Research 19 (pp. 151-220). New York: Academic Press.

Lane, L. C. (1977). Brome mosaic virus. CMI/AAB. Description of Plant Viruses, No. 180.

Mise, K., \& Pocsai, E. (2004). Brome mosaic. In H. Lapierre, \& P. A. Signoret (Eds.), Viruses and virus diseases of Poaceae (Gramineae) (pp. 735-739). Paris: INRA.

Ni, P., Vaughan, R. C., Tragesser, B., Hoover, H., \& Kao, C. K. (2014). The plant host can affect the encapsidation of brome mosaic virus (BMV) RNA: BMV virions are surprisingly heterogeneous. Journal of Molecular Biology, 426, 1061-1076.
Poscai, E. (1987). Effect of brome mosaic virus infection of the plant height and weight of cereals at their early stages of growth. Cereal Reasearch Communication 15(2-3), 167-174.

Ripplinger, J., \& Sullivan, J. (2008). Does choice in model selection affect maximum likelihood analysis? Systematic Biology, 57(1), 76-85. doi:10.1080/10635150801898920.

Ronquist, F., Teslenko, M., van der Mark, P., Ayres, D. L., Darling, A., Höhna, S., et al. (2012). MrBayes 3.2: efficient Bayesian phylogenetic inference and model choice across a large model space. Systematic Biology, 61(3), 539-542. doi:10.1093/ sysbio/sys029.

Rosen, S., \& Skaletsky, H. J. (2000). Primer3 on the WWW for general use and for biologist programmers. In S. Misener, \& S. A. Kravetz (Eds.), Bioinformatics Methods and Protocols, Methods in Molecular Biology (vol. 132, pp. 365-386). Totowa: Humana Press.

Rybicki, E. P., \& von Wechmar, M. B. (1982). Characterisation of an aphid-transmitted virus disease of small grains. Phytopathologische Zeitschrift, 103, 306-322.

Sambook, J., Fritsch, E. F., \& Maniatis, T. (1989). Molecular Cloning. A Laboratory Manual (2nd ed., pp. 7.43-7.45). Woodbury: Cold Spring Harbor Laboratory Press.

Scholthof, K. B. G., Adkins, S., Czosnek, H., Palukaitis, P., Jacquot, E., Hohn, T., et al. (2011). Top 10 plant viruses in molecular plant pathology. Molecular Plant Pathology, 12, 938-954. doi:10.1111/j.1364-3703.2011.00752.x.

Schwarz, G. (1978). Estimating the dimensions of a model. The Annals of Statistics, 6, 461-464.

Szabolcs, J., \& Gáborjányi, R. (1991). Brome mosaic virus transmission by cereal leaf beetle (Oulema melanopus, Coleoptera, Chrysomelidae). Acta Phytopathologica Et Entomologica Hungarica, 26(1-2), 203-206.

Tamura, K., Stecher, G., Peterson, D., Filipski, A., \& Kumar, S. (2013). MEGA6: Molecular Evolutionary Genetics Analysis Version 6.0. Molecular Biology and Evolution, 30, 27252729.

Trzmiel, K., Szydło, W., Zarzyńska-Nowak, A., \& Jeżewska, M. (2015). First report of Brome mosaic virus (BMV) and Wheat streak mosaic virus (WSMV) co-infection in triticale plants in Poland. Plant Disease, 99(9), 1290.

von Wechmar, M. B. (1980). Transmission of Brome mosaic virus by Puccinia graminis tritici. Phytopathologische Zeitschrift, 99, 289-293. 